\title{
21. A TEKTITE LAYER IN UPPER EOCENE SEDIMENTS OF THE NEW JERSEY CONTINENTAL SLOPE (SITE 612, LEG 95) ${ }^{1}$
}

\author{
Jean Thein, Universität des Saarlandes ${ }^{2}$
}

\begin{abstract}
At Site 612 (Leg 95), a 20-cm-thick layer containing microtektitic glass spherules separates middle Eocene from upper Eocene siliceous nannofossil oozes. These microtektites presumably are part of the widespread microtektite strewn field of late Eocene age, found in the Gulf of Mexico, the Caribbean Sea, the equatorial Pacific, and the eastern equatorial Indian Ocean. Associated large green tektite or impact glass fragments and shock-damaged silicate minerals demonstrate the impact origin of the Site 612 layer. The age of the layer remains uncertain, as a gap of about $6 \mathrm{~m} . \mathrm{y}$. separates the uppermost recovered middle Eocene (Bartonian) from the superjacent upper Eocene (upper Priabonian) sediments. However, geochemical and mineralogical composition as well as micropaleontological dating relate the bed to the lowermost of the three known late Eocene "North American" tektite layers.
\end{abstract}

\section{INTRODUCTION}

In the last decade, numerous deep sea drilling sites yielded sand-sized spherical to irregular droplets of silica glass in uppermost Eocene siliceous sediments (Donnely and Chao, 1973; Glass et al., 1973, 1985; Maurasse and Glass, 1976; Zwart, 1977; Glass and Zwart, 1979; Keller et al., in press). Recently a similar layer was found in pelagic chalks of the same age on Barbados (Sanfilippo et al., 1985; Glass et al., 1985, Keller et al., in press). Glass et al. (1985) describe a lower clinopyroxine-bearing layer and a slightly younger microtektite horizon in the late Eocene Globorotalia cerroazulensis foraminifer Zone and in the Calocyclas bandyca and Cryptoprora ornata radiolarian zones. The upper horizon is correlated with the North American tektites (including bediasites, Georgia tektites, and the Martha's Vineyard tektite), which were not found in situ, but to which a probable latest Eocene age is attributed (Barnes, 1940; O'Keefe, 1976, 1980; Rost, 1972).

Keller et al. (1983, in press) distinguish three Eocene microtektite layers on the basis of micropaleontological and geochemical comparisons: the two described by Glass et al. (1985) and one additional layer in the upper P15 foraminiferal zone (Globigerina semiinvoluta).

These microtektites and clinopyroxene-bearing spherules are interpreted today almost unanimously to be products of large cosmic impacts on the Earth's crust, although O'Keefe $(1976,1984)$ still relates them to catastrophic volcanic eruptions on the Earth's moon. Geochemical similarities, concordant radiometric ages, and geographic vicinity relate some tektite strewn fields to known impact structures: Ivory Coast tektites-Bosumtwi Crater (Glass et al., 1979; Shaw and Wasserburg, 1982), Moldavites-Nördlinger Ries (Faul 1966; Rost,

\footnotetext{
${ }^{1}$ Poag, C. W., Watts, A. B., et al., Init. Repts. DSDP, 95: Washington (U.S. Govt. Printing Office).

2 Address: Fachrichtung 15.5, Angewandte Geochemie, Universität des Saarlandes, D6600 Saarbrücken, Federal Republic of Germany.
}

1972), Irghizites-Zamanshin Crater (O'Keefe, 1984). An impact crater related to the North American tektites has not yet been found, although the catastrophe produced an estimated 5 billion tons of melt glass (Glass et al., 1985), spread over half the Earth's surface.

Upper Eocene siliceous sediments of Site 612 yielded numerous microtektites and tektite glass fragments; this new occurrence considerably extends the known strewn field of the North American microtektites in the western North Atlantic.

\section{GEOLOGIC AND STRATIGRAPHIC SETTING OF THE TEKTITE LAYER}

Site 612 was drilled on the upper continental slope off New Jersey (Fig. 1). The more than $670 \mathrm{~m}$ thick sequence of pelagic to hemipelagic sediments recovered reaches from upper Campanian bituminous marls to Pleistocene periglacial muds. This succession is interrupted by a number of major lithologic unconformities, corresponding in some cases to large stratigraphic gaps (Figs. $1,2,3$ ) (see also Poag and Low, this volume; Cousin and Thein, this volume). These unconformities result from erosion related to either eustatic fluctuations or deep water currents.

The prominent unconformity in Sample 612-21-5, $119 \mathrm{~cm}$ caps the long-lasting uniform deposition of siliceous nannofossil oozes and porcellanites during the early and middle Eocene (Fig. 2). The unconformity is overlain by a 20-cm-thick dark layer of clayey to sandy ooze, lacking the typical bioturbation of the adjacent sediments. At its base this layer contains centimeter-long glass fragments and smaller, colorless glass spherules; in the upper part are spherical to irregular sand-sized glass particles. The size of the glass fragments and abundance of silicate and glauconite grains diminishes toward the top of the zone. The lithology progressively grades into the medium gray upper Eocene siliceous nannofossil ooze, which is similar to the underlying middle Eocene sediment. Bioturbation reappears in the upper part of the microtektite layer. According to Poag and Low (this vol- 


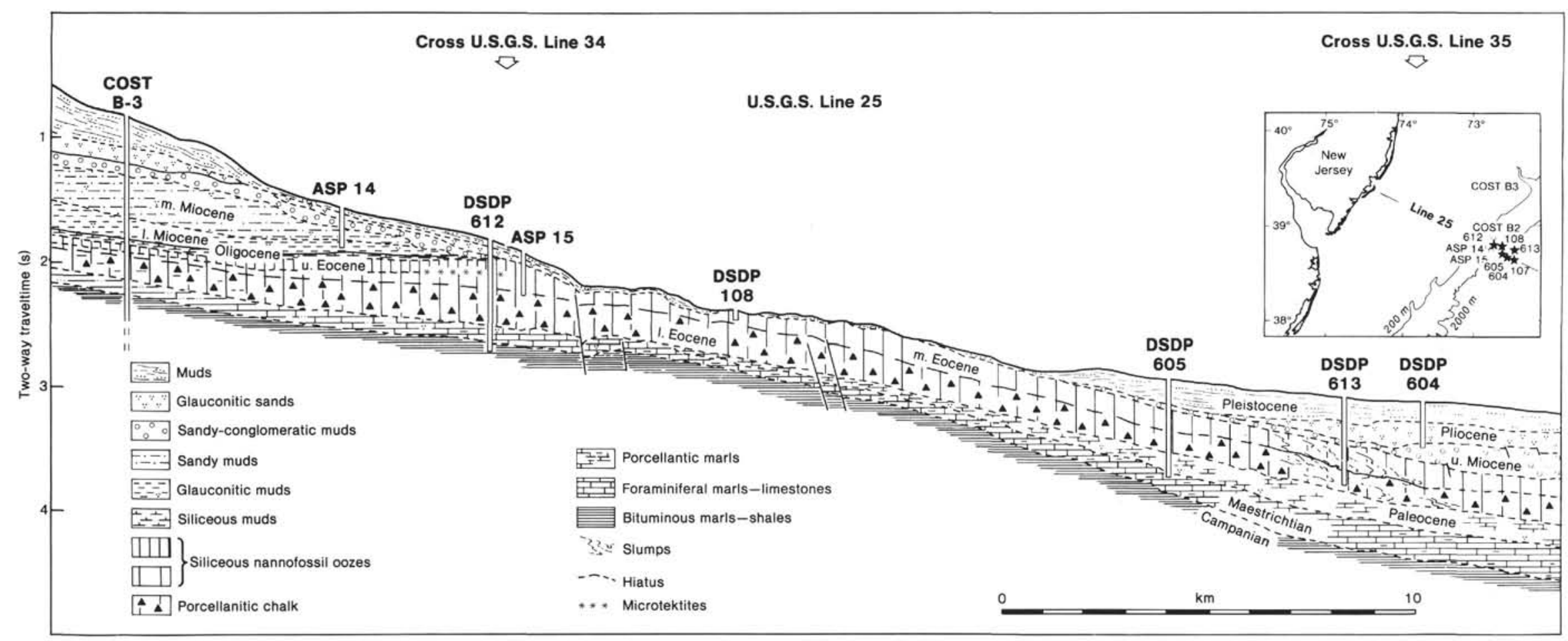

Figure 1. Schematic geologic cross section of the New Jersey Transect and location of Site 612 (modified after Poag, 1985). 

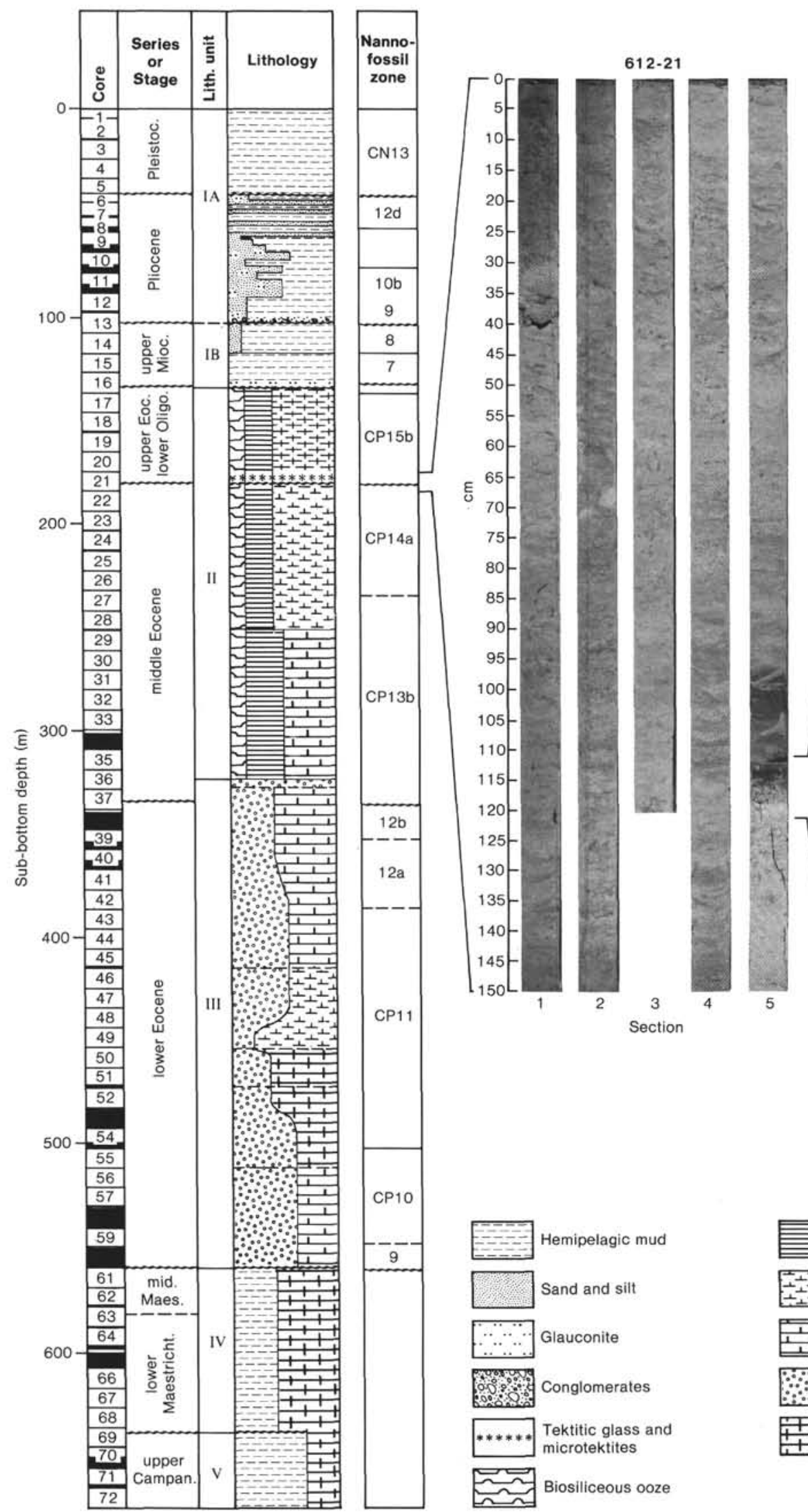

$612-21-5$
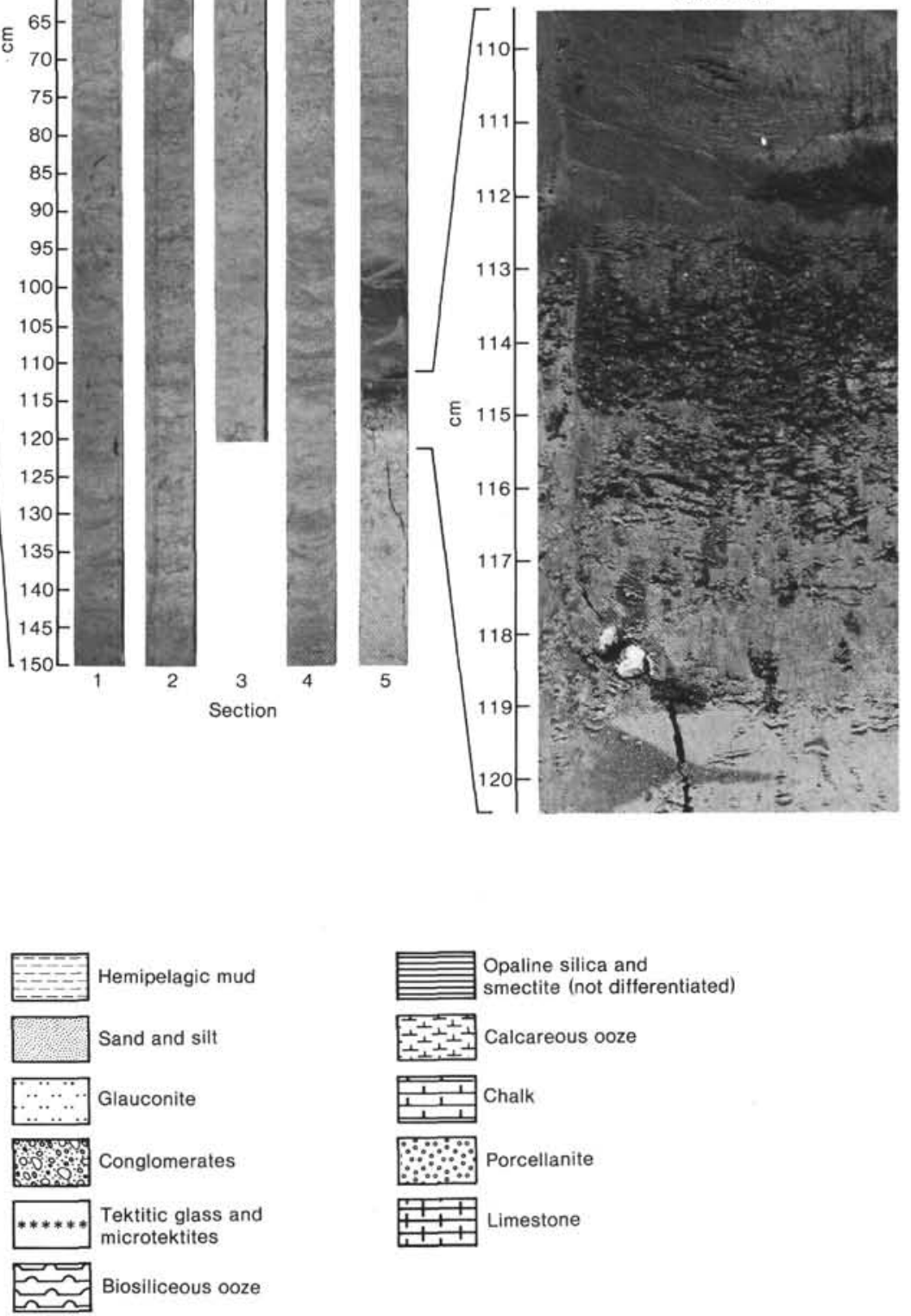

Figure 2. Lithologic section of Site 612, shipboard core photos, and close-up of the late Eocene tektite layer. Note the large, dark, vitric grains at the base of the microtektite layer which are large tektite fragments. 
ume) and Palmer (this volume), the unconformity at the base of the dark layer represents a stratigraphic gap of 6 m.y. (Fig. 3). Sediments are truncated in the Bartonian or Lutetian (assigned to nannofossil Biozone CP14a or planktonic foraminiferal Zone P11 and the Podocyrtis mitra radiolarian Zone); deposition started again in the late Priabonian (nannofossil Zone CP15, Cryptoprora ornata radiolarian zone).

The sharp base and the gradual lithologic and geochemical transition to the top (Fig. 4) favors the inter-

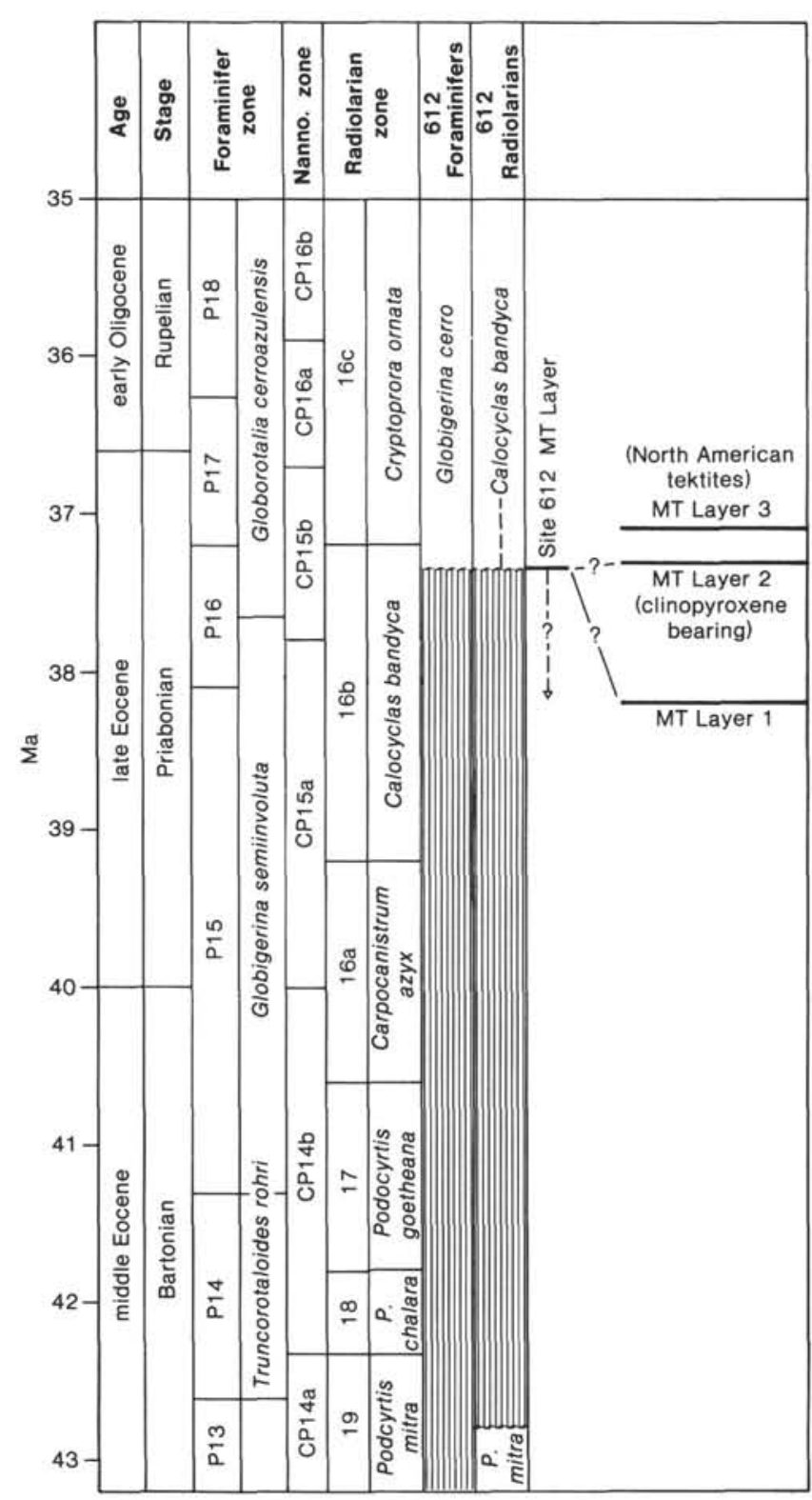

Figure 3. Biostratigraphic position of the Site 612 microtektite (MT) layer, compared to the three separate microtektite layers observed in the late Eocene North American strewn field. As the Site 612 layer is probably reworked, a minimum age is indicated. (Poag and Low place the contact between foraminiferal Zones P11 and P15, which yields a somewhat different stratigraphy than is shown here.) Stratigraphic data for Site 612 modified from Poag and Low (foraminifers) and Palmer (radiolarians) (both this volume) and Valentine (nannofossils; see Site 612 chapter). pretation that the layer forms the base of the upper Eocene section. Slight reworking may have occurred, although the presence of large, fresh, very angular feldspar grains argues against extensive winnowing of the sediment.

\section{MINERALOGICAL COMPOSITION}

The major coarse-grained component consists of spherical or irregular (more rarely teardrop to dumbbell shaped) glass grains (Plate 1). I observed the grains in a thin section from Sample 612-21-5, 111-114 cm, prepared by M. Cousin (Villefranche).

The largest spherules and irregular shards, reaching $2 \mathrm{~mm}$ in diameter, are found in the lower part of the thin section. Centimeter-sized glass fragments were detected in a $3-\mathrm{cm}^{3}$ geochemical sample (Sample 612-21-5, 118$119 \mathrm{~cm}$ ). Unfortunately, these were discovered as the sample was crushed for geochemical preparation. The grains were damaged and may have been damaged during the crushing process. One fragment, $7 \mathrm{~mm}$ long and weighing $0.66 \mathrm{~g}$, was preserved from complete destruction (Plate 2, Fig. 1). As several shards splintered off it, the original length certainly was greater. Shipboard core photos (Fig. 2) reveal centimeter-sized dark components of vitreous luster at this depth, stuck irregularly in the ooze of the basal layer. They could represent similar glass grains. In this basal part of the layer only a few irregular spherules have been observed (Plate 3, Figs. 4-6).

The large glass fragments in the lower part of the layer are dark brownish green, almost opaque. Thin shards are olive green, occasionally with a pinkish hue. The exposed surface is rough, corroded, and covered with small solution pits (Plate 2, Figs. 1, 2, 5). The freshly broken surfaces are perfectly smooth, even under high magnification (Plate 2, Figs. 3, 5), except for small oblong areas with pumice-like, scoriaceous structure (Plate 2, Fig. 6).

Typical for the green glass shards is a high density of small, up to millimeter-sized, spherical gas bubbles (Plate 2, Figs. 1-5, Plate 3, Figs. 1-5). Some of them are elongated and tubelike (Plate 2, Fig. 3). Long fusiform bubbles, sometimes containing fluid, were observed in the clear glass droplets in Sample 612-21-5, 118-119 cm (Plate 3, Figs. 4, 6). Such features have not previously been reported in North American tektites (where spheres are most characteristic), but are common in Muong Nongtype tektites and Darwin glass (Barnes, 1973).

The few irregular glass spheres in the basal part of the layer, associated with the green glass, are translucent and colorless. They display a fine lamination, because of their internal fluid texture.

The smaller glass particles on the thin section (Sample $61-21-5,111-114 \mathrm{~cm}$ ) show a variety of forms, ranging from spherical, often with large pits, to teardrop and dumbbell shaped. Most of them are, however, highly irregular and angular (Plate 1, Figs. 1-3, Plate 4, Figs. 14 ). They consist of clear colorless glass, often bearing smaller gas bubbles, which rarely are so large that a hollow sphere is formed. Irregular schlieren, fluid texture, and perlitic fractures are most typical for the irregular grains (Plate 5, Fig. 1). Inclusions of unmolten silicate grains, irregular inclusions of lechatelierite (Plate 1, Fig. 3) or schlieren of dark brown glass are common. 


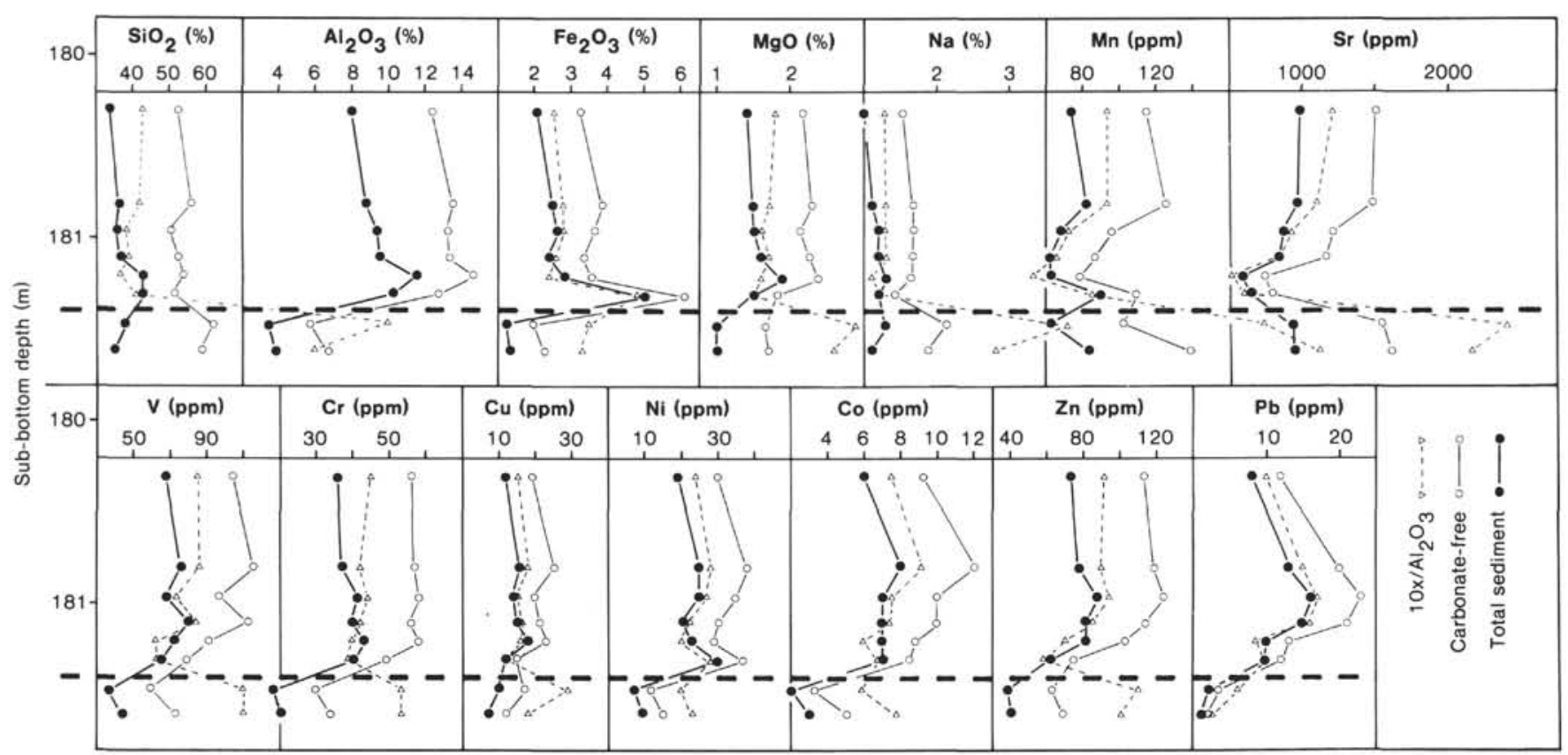

Figure 4. Vertical element distribution across the middle/upper Eocene unconformity. Heavy dashed line marks the unconformity.

Recrystallization (or possibly diagenetic alteration) invading the glass grains from the outer rim or embracing the complete grain is rather rare (Plate 4, Figs. 5, 6).

Almost all glass particles of the thin section are rimmed by sulfide minerals, which occasionally grow into the glass interior (Plate 1, Fig. 3, Plate 4, Fig. 4), sometimes along perlitic cracks. Sulfides are dispersed over all the layer and replace foraminifers and radiolarians. This suggests that the sulfide formation is a general diagenetic process, which is excessive in this horizon compared to other unconformities in the section. It might reflect anaerobic conditions after the deposition of the microtektite layer (see also Poag and Low, this volume).

The refractive index $\left(n_{\mathrm{D}}\right)$ varies for the green glass between 1.502 and 1.515; for the colorless glass, values from 1.495 to 1.505 were found (measured by A. Mihm, Saarbrücken).

Rare grains of foamy, pumice-like, inclusion-rich glass (Plate 5, Figs. 2, 3) resemble the highly degassed, waterrich parts of Arizona Crater Cocconino Sandstone (Plate 5, Fig. 4), or the scoriaceous silicate particles described by Kyte and Brownlee (1985) in an impact ashfall layer in the late Pliocene of the southeastern Pacific.

Of fundamental interest in this layer are the detrital minerals associated with the glass grains: very poorly sorted, fresh and highly angular quartz and feldspar crystal fragments and rare glauconite pellets. Both quartz and feldspar grains display signs of shock metamorphism. The quartz is not only undulatory, but larger grains often shown rhombohedral planar fractures (Plate 5, Fig.

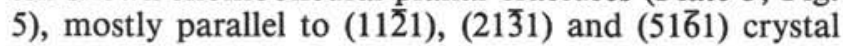
planes (measured by G. Graup, Mainz). The grains occasionally show single sets of planar features. The large feldspar fragments are highly undulatory and fractured, with bent and kinked cleavage planes. Some of them are partially changed to thetomorphic glass (Plate 5, Fig. 6).
To summarize, the "microtektite layer" of Site 612 resembles an impact breccia; the green glass appears to be impact glass. The layer, however, has a high fraction of marine pelagic sediment (as shown by the radiolarian, foraminifer, and nannofossil components of the finegrained part), and so it probably has been redeposited by sedimentary processes.

\section{BULK SEDIMENT GEOCHEMICAL COMPOSITION}

Alvarez et al. (1980), Smit and Hertogen (1980), and a number of other authors have assumed that the boundary clay at the Cretaceous/Tertiary boundary is the product of the ash fall of a large cosmic impact on the earth. Their major argument is the enrichment of exotic cosmogenic platinum group metals, especially iridium, and levels of chalcophilic and siderophilic elements far beyond the values found below and above the boundary clay. In some sections, microtektite-like silicate spherules have been identified in the boundary clay (Smit and Klaver, 1981; Smit and Romein, 1985).

As there is little doubt that microtektites are the products of large impacts, geochemical analyses have also been attempted on microtektite-enriched layers, especially in the "North American" tektite strewn field. Enhanced Ir values have been found in the matrix sediments of the layers or slightly below by Ganapathy (1982a, b), Asaro et al. (1982), and Alvarez et al. (1982). Keller et al. (in press) identified an Ir anomaly associated with the clinopyroxene-bearing microtektite layer on Barbados.

I sampled Site 612 sediments for normal sediment geochemical analyses. Bulk chemical analyses were obtained for samples immediately above and below the microtektite layer (Fig. 4). Unfortunately, sample density is not high enough to detect possible element enrichments in the layer itself. In the basal part of the layer, only the 
glass fragments and the coarse-grained sediment fraction were recovered, but fine-grained sediments were insufficient for a chemical bulk analysis.

In the complete chemostratigraphic section of Site 612, the microtektite layer coincides with a sharp change in the chemical and lithologic bulk composition pattern. Figure 4 shows the elemental pattern in the immediate stratigraphic vicinity of the layer on a larger scale. A prominent enrichment is obvious for $\mathrm{Fe}$ and $\mathrm{Ni}$, as well as for the terrigenous elements such as $\mathrm{Al}$ (although not represented in Fig. 4, $\mathrm{Ti}$ and $\mathrm{K}$ are also enriched). $\mathrm{CaCO}_{3}$, $\mathrm{Sr}, \mathrm{Na}$, and $\mathrm{Mn}$ values drop sharply above the unconformity, reaching normal values again several centimeters above the microtektite layer.

When recalculated on a $\mathrm{CaCO}_{3}$-free basis, or normalized to the $\mathrm{Al}_{2} \mathrm{O}_{3}$ (clay) content of the sediment, these anomalies disappear. The enrichment of $\mathrm{Fe}$ and slightly enhanced $\mathrm{Ni}$ values persist, however, suggesting the admixture of small amounts of meteoritic material with the sediment layer. $\mathrm{Na}, \mathrm{Mn}$, and $\mathrm{Sr}$ are strongly depleted, reflecting the dilution of biogenic and authigenic elements by input of terrigenous clastics to the layer.

Preliminary Ir analyses by neutron activation (U. Rast, Mainz) yielded no significant values of this "cosmic tracer" in the bulk sediment samples. The Ir contents, however, lie mostly below the detection limit of the method, as do the peak values for the clinopyroxene-bearing microtektite layer described by Keller et al. (in press). More accurate analyses on a denser sample grid are necessary to give more reliable results.

\section{CHEMICAL COMPOSITION OF THE GLASS FRAGMENTS}

Preliminary scanning electron microscope chemical analyses have been carried out by G. Graup (Mainz) on polished thin sections of the green glass. U. Rast (Mainz) measured trace element contents on five grains by neutron activation. Table 1 shows the results.

The mean values for the major element composition fit with the data published for the North American microtektites (Glass et al., 1985; Ngo et al., 1985; Keller et al., in press) (Fig. 5). The green glass appears to be rather homogeneous, as the results of 10 separate measurements on different positions vary only slightly (Table 1). The highest standard deviation is noted for $\mathrm{Na}$, a fact observed also by other authors, and is probably a result of analytical effects as well as the high volatility and mobility of the element. The results given in Table 1 are normalized to $100 \%$. The real oxide sums vary from 95.54 to $97.99 \%$, with a mean value of $96.81 \%$ and a standard deviation of $0.9 \%$. Hydratization during diagenetic alteration is probably the reason for this low oxide sum. The major element composition proves clearly the tektite character of the Site 612 upper Eocene glasses. The mean values projected in the $\mathrm{SiO}_{2}$-element oxide crossplots of Figure 5 suggest the green glass is the same as the upper layer of the North American tektites, as well as bediasite and Georgia tektite glasses.

The trace element data in Table 1 are preliminary, but are in good agreement with the data published on "North American" tektite glass (Barnes, 1973).
Table 1. Major and trace element composition of green glass from Sample 612-21-5, $118 \mathrm{~cm}^{\mathrm{a}}$

\begin{tabular}{lrrrrr}
\hline & Mean & Minimum & Maximum & $\begin{array}{r}\text { Standard } \\
\text { deviation }\end{array}$ \\
\hline $\mathrm{SiO}_{2}$ & $73.60 \%$ & $72.32 \%$ & $75.43 \%$ & 1.04 & \\
$\mathrm{Al}_{2} \mathrm{O}_{3}$ & $15.33 \%$ & $14.46 \%$ & $16.25 \%$ & 0.56 & \\
$\mathrm{FeO}$ & $4.77 \%$ & $4.50 \%$ & $4.96 \%$ & 0.15 & \\
$\mathrm{~K}_{2} \mathrm{O}$ & $3.77 \%$ & $3.60 \%$ & $3.93 \%$ & 0.10 & \\
$\mathrm{TiO}$ & $0.77 \%$ & $0.73 \%$ & $0.82 \%$ & 0.03 & \\
$\mathrm{CaO}$ & $0.72 \%$ & $0.67 \%$ & $0.77 \%$ & 0.03 & \\
$\mathrm{MgO}$ & $0.56 \%$ & $0.44 \%$ & $0.74 \%$ & 0.10 & \\
$\mathrm{Na}{ }_{2} \mathrm{O}$ & $0.44 \%$ & $0.00 \%$ & $0.90 \%$ & 0.32 & \\
$\mathrm{MnO}$ & $0.04 \%$ & $0.00 \%$ & $0.09 \%$ & 0.02 & Barnes $(1973)$ \\
$\mathrm{Zr}$ & $406 \mathrm{ppm}$ & $220 \mathrm{ppm}$ & $700 \mathrm{ppm}$ & 196 & $550 \mathrm{ppm}$ \\
$\mathrm{Rb}$ & $197 \mathrm{ppm}$ & $185 \mathrm{ppm}$ & $200 \mathrm{ppm}$ & 7 & $66-600 \mathrm{ppm}$ \\
$\mathrm{Sr}$ & $147 \mathrm{ppm}$ & $100 \mathrm{ppm}$ & $200 \mathrm{ppm}$ & 50 & $152-550 \mathrm{ppm}$ \\
$\mathrm{Ce}$ & $99 \mathrm{ppm}$ & $95 \mathrm{ppm}$ & $100 \mathrm{ppm}$ & 2 & - \\
$\mathrm{Cr}$ & $48 \mathrm{ppm}$ & $45 \mathrm{ppm}$ & $52 \mathrm{ppm}$ & 3 & $30-40 \mathrm{ppm}$ \\
$\mathrm{Nd}$ & $45 \mathrm{ppm}$ & $40 \mathrm{ppm}$ & $52 \mathrm{ppm}$ & 6 & - \\
$\mathrm{La}$ & $43 \mathrm{ppm}$ & $41 \mathrm{ppm}$ & $46 \mathrm{ppm}$ & 2 & $42 \mathrm{ppm}$ \\
$\mathrm{Co}$ & $16 \mathrm{ppm}$ & $12 \mathrm{ppm}$ & $19 \mathrm{ppm}$ & 3 & $10 \mathrm{ppm}$ \\
$\mathrm{Ga}$ & $12 \mathrm{ppm}$ & $10 \mathrm{ppm}$ & $12 \mathrm{ppm}$ & 1 & - \\
$\mathrm{Sm}$ & $8 \mathrm{ppm}$ & $8 \mathrm{ppm}$ & $8 \mathrm{ppm}$ & 0.1 & $4.4 \mathrm{ppm}$ \\
$\mathrm{Ir}$ & $7 \mathrm{ppb}$ & & & & - \\
\hline & & & & & \\
\hline
\end{tabular}

a Major element analysis by scanning electron microscope on polished thin section (analyst: G. Graup). Trace element analysis by neutron activation (analyst: U. Rast).

\section{DISCUSSION}

On the basis of these preliminary results, there is little doubt that the large glass spherules and fragments found in the $20-\mathrm{cm}$-thick layer above the unconformable middle/upper Eocene contact at Site 612 are microtektites and impact glass, respectively. These presumably were generated by the impact of a large cosmic body on the Earth's surface. These particles appear to belong to one of the known microtektite layers described in the Atlantic, Caribbean, and Pacific as "North American" microtektites sensu lato, and being of late Eocene age.

The glass spherules of Site 612 should be considered microtektites (including all impact-generated spherules). Although they may exceed by $2 \mathrm{~mm}$ the limiting dimension of $1 \mathrm{~mm}$ for microtektites, the mean size is about $0.2 \mathrm{~mm}$. Apparently there is normally a gradual transition from large impact melt ejecta in the vicinity of an impact site to progressively smaller glass fragments and spherules, depending on the original grain size of the ejecta and the impact energy. Graup (1981) described spherical glass grains and chondrules in the distal facies of the Nördlinger Ries suevite (impactite). Glass et al. (1985) found a large glass fragment in the upper Eocene microtektite layer of the Bath Cliff section, Barbados.

The Site 612 microtektite layer differs in some respects from the other known upper Eocene microtektite layers:

1. The spherical and teardrop-shaped microtektites are exceptionally large (as much as $2 \mathrm{~mm}$ diameter).

2. They are associated with numerous glass shards of irregular shape, but of similar or larger size.

3 . They occur together with centimeter-sized glass fragments which, from their highly degassed character and numerous remains of unmolten silicate mineral grains, resemble normal impact melts of tektites of the MuongNong type. 

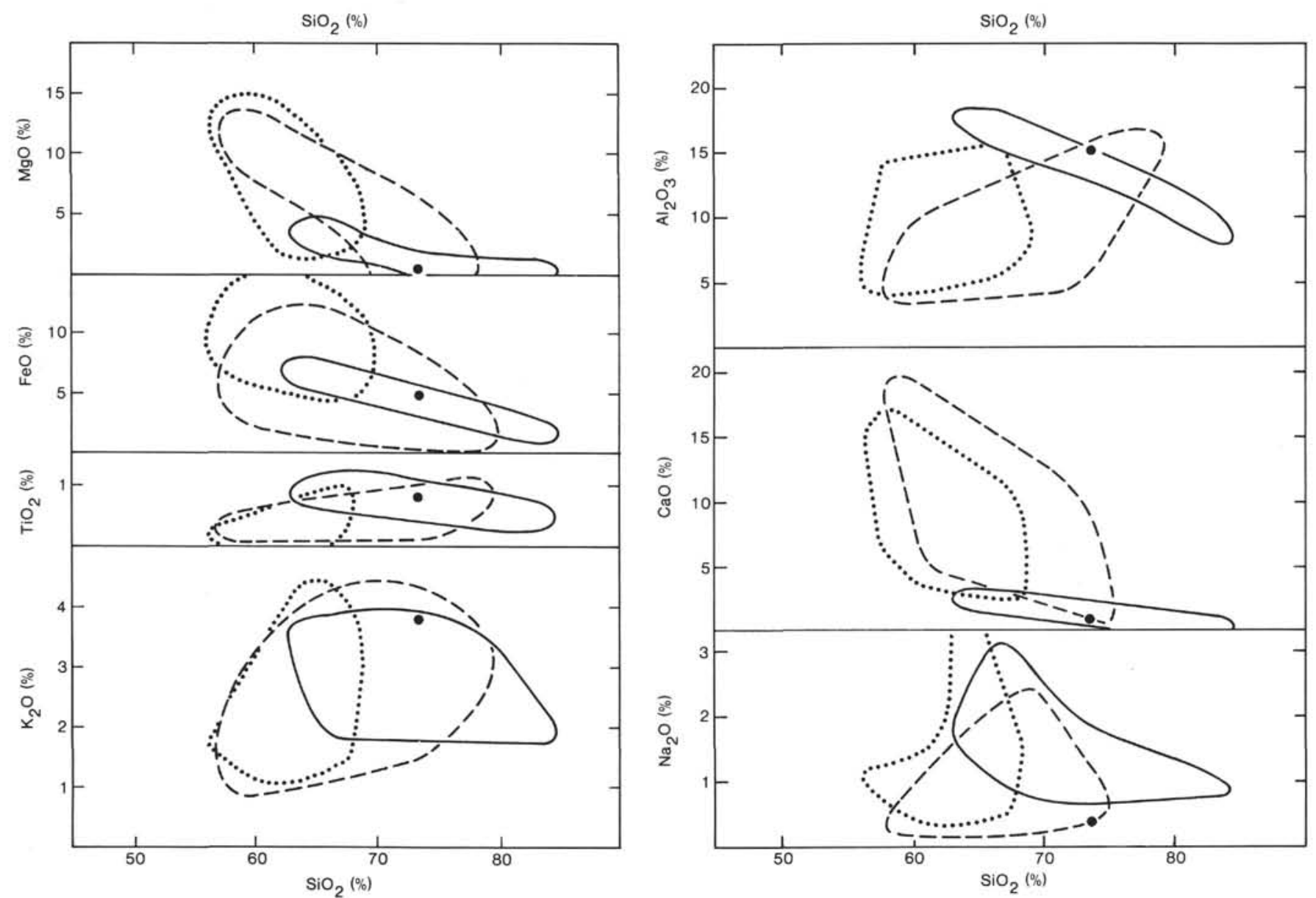

Figure 5. Relationship of Site 612 green glass to geochemical distribution plots for other late Eocene microtektite layers. Black dots represent the mean chemical composition of Site 612 glass. Solid lines limit the composition fields of "North American" tektites and microtektites (Layer 3 of Fig. 3); dotted lines limit the composition fields of the clinopyroxene-bearing spherules (Layer 2 of Fig. 3); dashed lines represent the fields of variance of Layer CP15 microtektites (Layer 1 of Fig. 3). (Modified from Keller et al., in press.)

4. They are associated with large silicate grains, which show features of shock metamorphism.

This exotic glass and mineral composition relates the layer to a normal, fine-grained distal impact breccia, which seems to have been reworked, as shown by the biogenic and glauconitic components, and as suggested by the stratigraphic gap below this boundary layer. Nevertheless, it bears the following implications:

1. It expands the strewn field known for the upper Eocene microtektites and tektites appreciably to the north and links the Martha's Vineyard tektite to the other occurrences (Fig. 6).

2. It confirms that microtektites can occur together with tektites and impact glass, as already suggested by the finds on Barbados (assuming that they were not brought together by reworking processes). The stratigraphic position of the bediasites and Georgia tektites should be revised. They must, be older than previously supposed, or else there is another macrotektite strewn field of nannofossil Zone CP15 age.

3 . The presence of shocked minerals suggests that tektites and microtektites are both products of cosmic impact. Bohor et al. (1984) described shocked quartzes from the Cretaceous/Tertiary boundary, which, however, do not occur together with glassy spherules. Microtektitelike silicate spheres were observed at the Cretaceous/Tertiary boundary by Smit and Klaver (1981) and Smit and Romein (1985) in other sections. Their impact-melt character remains to be proven.

4. The large size of both glasses and shocked minerals suggests the generating impact crater(s) is not too far from Site 612 (hundreds of kilometers?). This assumption eliminates the candidates previously considered (Popigai, Wanapitai, etc.) and makes more attractive the suggestion of Shaw and Wasserburg (1982) that the crater must be somewhere on the northeast American shelf or slope. Wanapitai crater can also be excluded on the base of isotopic geochemical arguments (Ngo et al., 1985).

Some comments should be made on the shape of the strewn field as drawn by Glass (1982), Glass et al. (1985), and Keller et al. (in press):

1. It resembles the dispersion cloud for volcanic ash and vapor of the El Chichon eruption in 1982, which spread in just 14 days over the same area that is covered by the strewn field (McCormick and Swissler, 1983). This suggests a possible transport of the impact ash by equa- 


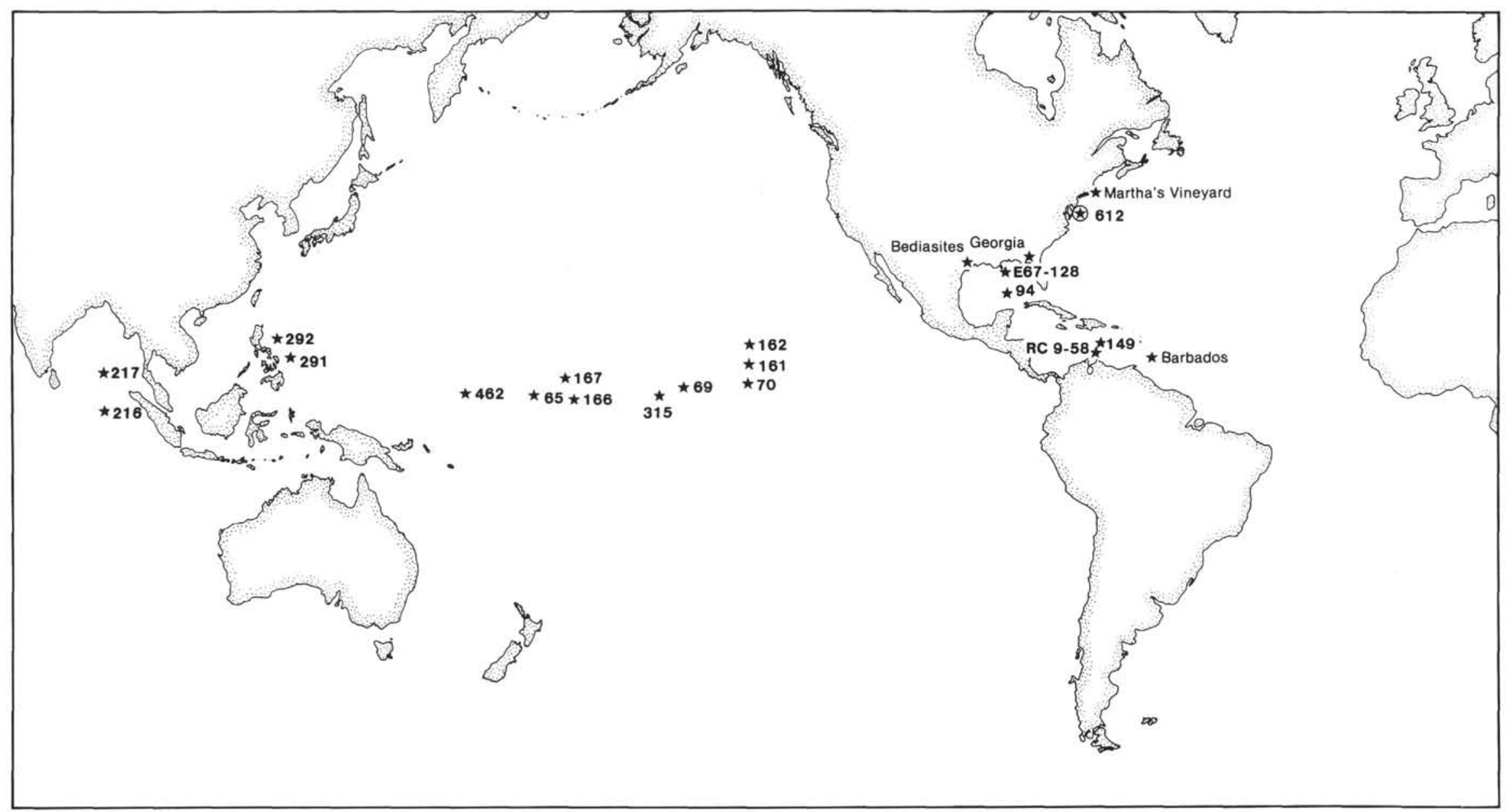

Figure 6. Strewn field of late Eocene "North American" tektites and microtektite layers, plotted on a map of modern continent position. (Modified after Glass et al. 1985; Keller et al., in press.) 
torial high stratospheric windstreams, although the larger materials at Site 612 (discussed above) could not have been transported in this way.

2. The observation of Glass et al. (1985) that microtektites are found only together with skeletons of siliceous organisms raises the question as to whether the strewn field as observed today might be the product of silica diagenesis, as impact glass could be dissolved and recrystallized in the same way as biogenic opal A.

3. Plate tectonics and seafloor spreading, which were not taken into account in construction of the strewn field (it is plotted on the map of modern continent positions), certainly would change the original shape of the strewn field.

The stratigraphic position of the Site 612 microtektite layer most reasonably correlates it with the lowest CP15 layer described by Keller et al. (in press). This would coincide with the low Ir contents as measured by neutron activation analysis. The geochemical composition of the large green glass fragments relates them to the bediasites and Georgia tektites, although this coincidence is not significant, as there is a wide overlapping of the elemental compositions of all late Eocene tektites. The isotopic compositions published by Ngo et al. (1985) group all late Eocene microtektites and tektites very closely and separate them clearly from the Ivory Coast and Australasian tektites. This assumes a common parent rock and one single impact event for all three layers (compare also the tektite ring idea of O'Keefe, 1980).

It is beyond the scope of this chapter to discuss fully all of these points or to resolve several controversial problems (e.g., whether the late Eocene impact event(s) influences biologic evolution). Apparently long-time effects seriously disturbed the development of radiolarians, although no real mass extinction is revealed during this period (Palmer, this volume; Keller et al., in press; Corliss et al., 1984).

Another unresolved problem is whether the impact was responsible for the drastic cooling event in the early Oligocene (Shackleton and Kennett, 1975; Glass, 1982).

Further investigations of the microtektite layer of Site 612 (in progress by the author, Graup and Rast) perhaps may help to answer these questions (or raise new ones).

\section{ACKNOWLEDGMENTS}

The author thanks G. Graup (Mainz) for the scanning electron microscope analyses on glass thin sections, universal stage measurements of quartz deformation planes, and very useful discussions; U. Rast (Munich) for trace element analyses with neutron activation; A. Mihm (Saarbrücken) for the determination of glass refractive indices; G. Keller (Princeton, NJ), K. Miller (Palisades, NY), C.W. Poag (Woods Hole, MA) and A. Palmer (College Station, TX) and two anonymous reviewers for their critical review of an early manuscript draft and their helpful suggestions.

\section{REFERENCES}

Alvarez, L. W., Alvarez, W., Asaro, F., and Michel, H. V., 1980. Extraterrestrial cause for the Cretaceous-Tertiary extinction. Science, 208:1095-1108.

Alvarez, W., Asaro, F., Michel, H. V., and Alvarez, L. W., 1982. Iridium anomaly approximately synchronous with terminal Eocene extinctions. Science, 216:886-888.

Asaro, F., Alvarez, L. W., Alvarez, W., and Michel, H. V., 1982. Geochemical anomalies near the Eocene/Oligocene and Permian/Triassic boundaries. Geol. Soc. Am. Spec. Pap., 190:517-528.
Barnes, V. E., 1940. North American tektites. Univ. Tex. Publ., 3945: 447-582.

1973. Tektites. In Barnes, V. E., and Barnes, M. A. (Eds.), Tektites: Stroudsburg, PA (Dowden, Hutchinson, and Ross), pp. 127-138.

Bohor, B. F., Foord, E. E., Modreski, P. J., and Triplehorn, D. M., 1984. Mineralogic evidence for an impact event at the CretaceousTertiary boundary. Science, 224:867-869.

Corliss, B. H., Aubry, M. P., Berggren, W. A., Fenner, J. M., Keigwin, L. D., Jr., and Keller, G., 1984. The Eocene/Oligocene boundary event in the deep sea. Science, 226:806-810.

Donnelly, T. W., and Chao, E. C. T., 1973. Microtektites of late Eocene age from the eastern Carribbean Sea. In Edgar, N. T., Saunders, J. B., et al., Init. Repts. DSDP, 15: Washington (U.S. Govt. Printing Office), 1031-1037.

Faul, H., 1966. Tektites are terrestrial. Nature, 152:1341-1344.

Ganapathy, R., 1982a. Evidence for a major meteorite impact on the Earth 34 million years ago: Implication for Eocene extinctions. Science, 216:885-886.

1982b. Evidence for a major meteorite impact on the Earth 34 million years ago: Implications on the origin of North American tektites and Eocene extinctions. Geol. Soc. Am. Spec. Pap., 190:513-516.

Glass, B. P., 1982. Possible correlations between tektite events and climatic changes? Geol. Soc. Am. Spec. Pap., 190:251-256.

Glass, B. P., Baker, R. N., Storzer, D., and Wagner, G. A., 1973. North American microtektites from the Caribbean Sea and Gulf of Mexico. Earth Planet. Sci. Lett., 19:184-192.

Glass, B. P., Burns, C. A., Crosbie, J. R., and DuBois, D. L., 1985. Late Eocene North American microtektites and clinopyroxene-bearing spherules. Proc. Lunar Planet. Sci. Conf. 15th., 1:175-195.

Glass, B. P., Swincki, M. B., and Zwart, P. A., 1979. Australasian, Ivory Coast and North American tektite strewnfields: Size, mass and correlation with geomagnetic reversals and other earth events. Proc. Lunar Planet. Sci. Conf. 10th., pp. 2535-2545.

Glass, B. P., and Zwart, M. J., 1979. North American microtektite layer in Deep Sea Drilling Project cores from the Caribbean Sea and Gulf of Mexico. Geol. Soc. Am. Bull., 90:595-602.

Graup, G., 1981. Terrestrial chondrules, glass spherules, and accretionary lapilli from the suevite, Ries Crater, Germany. Earth Planet. Sci. Lett., 55:407-418.

Keller, G., D'Hondt, S., Onstatt, T., Gilmore, C. G., Orth, C., Keigwin, L. D., and Shoemaker, E. M., in press. Stratigraphy, age and geochemistry of late Eocene impact events.

Keller, G., D'Hondt, S., and Vallier, T. L., 1983. Multiple microtektite horizons in upper Eocene marine sediments: No evidence for mass extinctions. Science, 221:150-152.

Kyte, F. T., and Brownlee, D. E., 1985. Unmelted meteoritic debris in a late Pliocene iridium anomaly: Evidence for the ocean impact of a nonchrondritic asteroid. Geochim. Cosmochim. Acta, 49:10951108.

McCormick, M. P., and Swissler, T. J., 1983. Stratospheric aerosol mass and latitudinal distribution of the El Chichón eruption cloud for October 1982. Geophys. Res. Lett., 10:877-880.

Maurasse, F., and Glass, B. P., 1976. Radiolarian stratigraphy and North American microtektites in Caribbean core RC9-58: Implications concerning the age of the Eocene-Oligocene boundary. Proc. 7th. Caribbean Geol. Conf., pp. 205-212.

Ngo, H. H., Wasserburg, G. J., and Glass, B. P., 1985. Nd and Sr isotopic composition of tektite material from Barbados and their relationship to North American tektites. Geochim. Cosmochim. Acta, 49:1429-1485.

O'Keefe, J. A., 1976. Tektites and their Origin: Amsterdam. 1980. The terminal Eocene event: Formation of a ring system around the earth? Nature, 285:301-311. 1984. Natural glass. J. Noncryst. Solids, 67:1-17.

Rost, R., 1972. Vltaviny a Tektity: Prag.

Sanfilippo, A., Riedel, W. R., Glass, B. P., and Kyte, F. T., 1985. Late Eocene microtektites and radiolarian extinctions on Barbados. $\mathrm{Na}$ ture, 314:613-615.

Shackleton, N. J., and Kennett, J. P., 1975. Paleotemperature history of the Cenozoic and the initiation of Antarctic glaciation: Oxygen and carbonate isotope analysis in DSDP Sites 277, 279 and 281. In Kennett, J. P., Houtz, R. E., et al., Init. Repts. DSDP, 29: Washington (U.S. Govt. Printing Office), 743-755. 


\section{J. THEIN}

Shaw, H. F., and Wasserburg, G. J., 1982. Age and provenance of the target materials for tektites and possible impactites as inferred from $\mathrm{Sm}-\mathrm{Nd}$ and Rb-Sr systematics. Earth Planet. Sci. Lett., 60:155177.

Smit, J., and Hertogen, J., 1980. An extraterrestrial event at the Cretaceous-Tertiary boundary. Nature, 285:198-200.

Smit, J., and Klaver, G., 1981. Sanidine spherules indicate a large impact event. Nature, 292:47-49.
Smit, J., and Romein, A. J. T., 1985. A sequence of events across the Cretaceous-Tertiary boundary. Earth Planet. Sci. Lett., 74:155-170.

Zwart, M. J., 1977. North American microtektites from Deep Sea Drilling Project cores [Ph.D. thesis]. University of Delaware, Newark.

Date of Initial Receipt: 14 August 1985 Date of Acceptance: 19 August 1986 

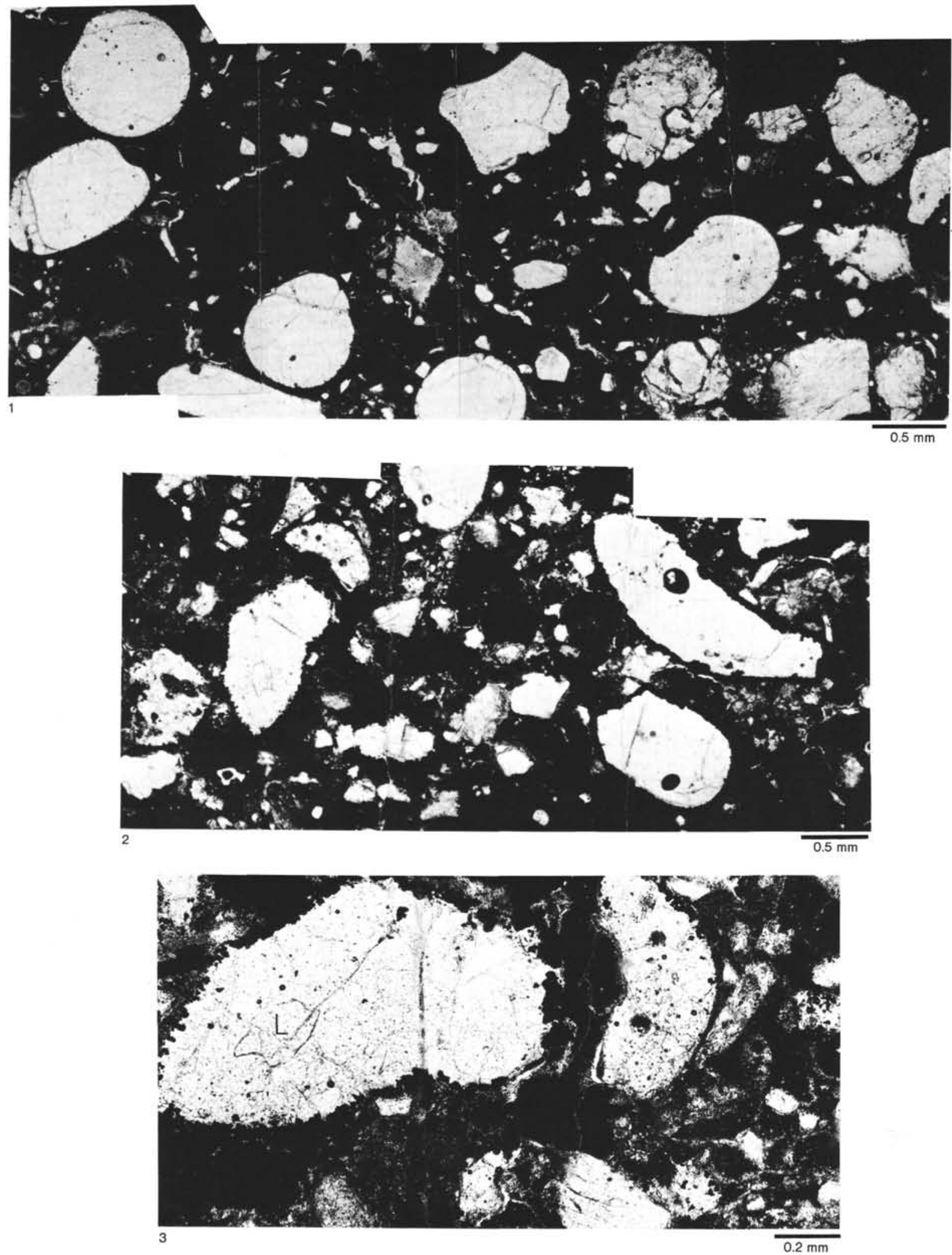

Plate 1. Thin section photomicrographs of microtektite layer (Sample 612-21-5, 111-114 cm, late Eocene). 1. Generalized view of siliceous nannofossil ooze with microtektites displaying spherical, tear-shaped, and irregular grain forms. In the central part of the photo is an irregular, recrystallized glass fragment. Lower right: feldspar and quartz grains with planar fractures. 2 . Siliceous nannofossil ooze with irregular to highly angular glass fragments. Note dark sulfidic rim around most grains. 3. Detail of fig. 2. Fractured irregular microtektites surrounded by sulfide rim. Sulfide also penetrates the tektite glass. The large grain on the left shows irregular lechatelierite inclusion (L). Lower middle: fractured feldspar crystal. 

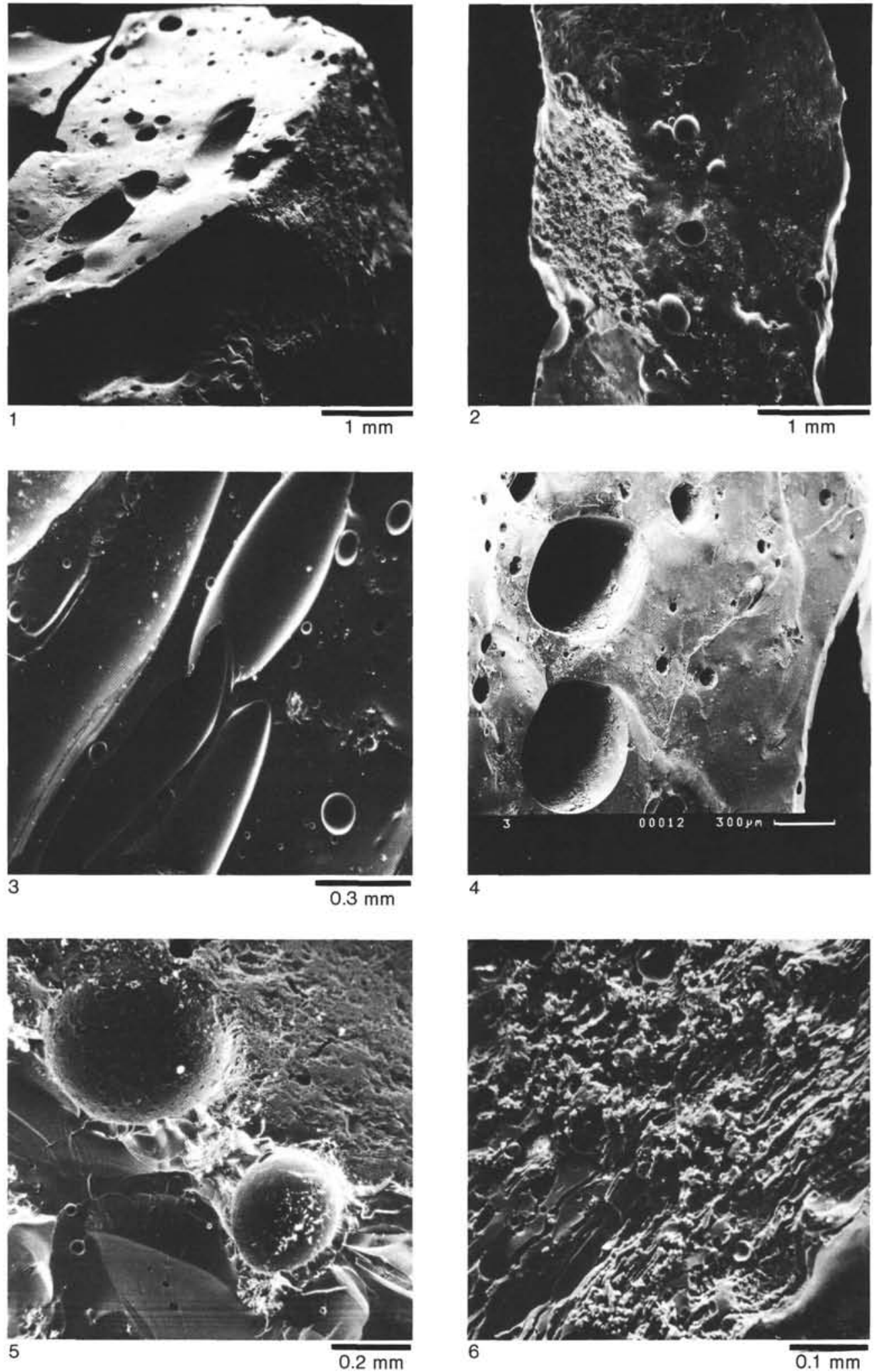

Plate 2. Scanning electron micrographs of large green glass fragments (Sample 612-21-5, $118 \mathrm{~cm}$, late Eocene). 1. Green glass with smooth, freshly broken, and strongly etched original surfaces. Note high density of spherical to ellipsoid gas bubbles of very different size. 2. Elongated, irregular glass grain. Original surface, partly corroded. Smooth parts display gas bubble pits. 3. Freshly broken surface with long, tube-like canals and small, spherical bubbles. 4.Detail of fig. 1, showing different types of gas bubbles, partly filled with sediment (secondary contamination). 5. Detail of fig. 1. Etched original surface and pits, juxtaposed to fresh, broken surface. Note typical conchoidal fractures. 6. Elongated lens with frosty, highly degassed, pumice-like glass, enclosed in dense glass of fig. 1 

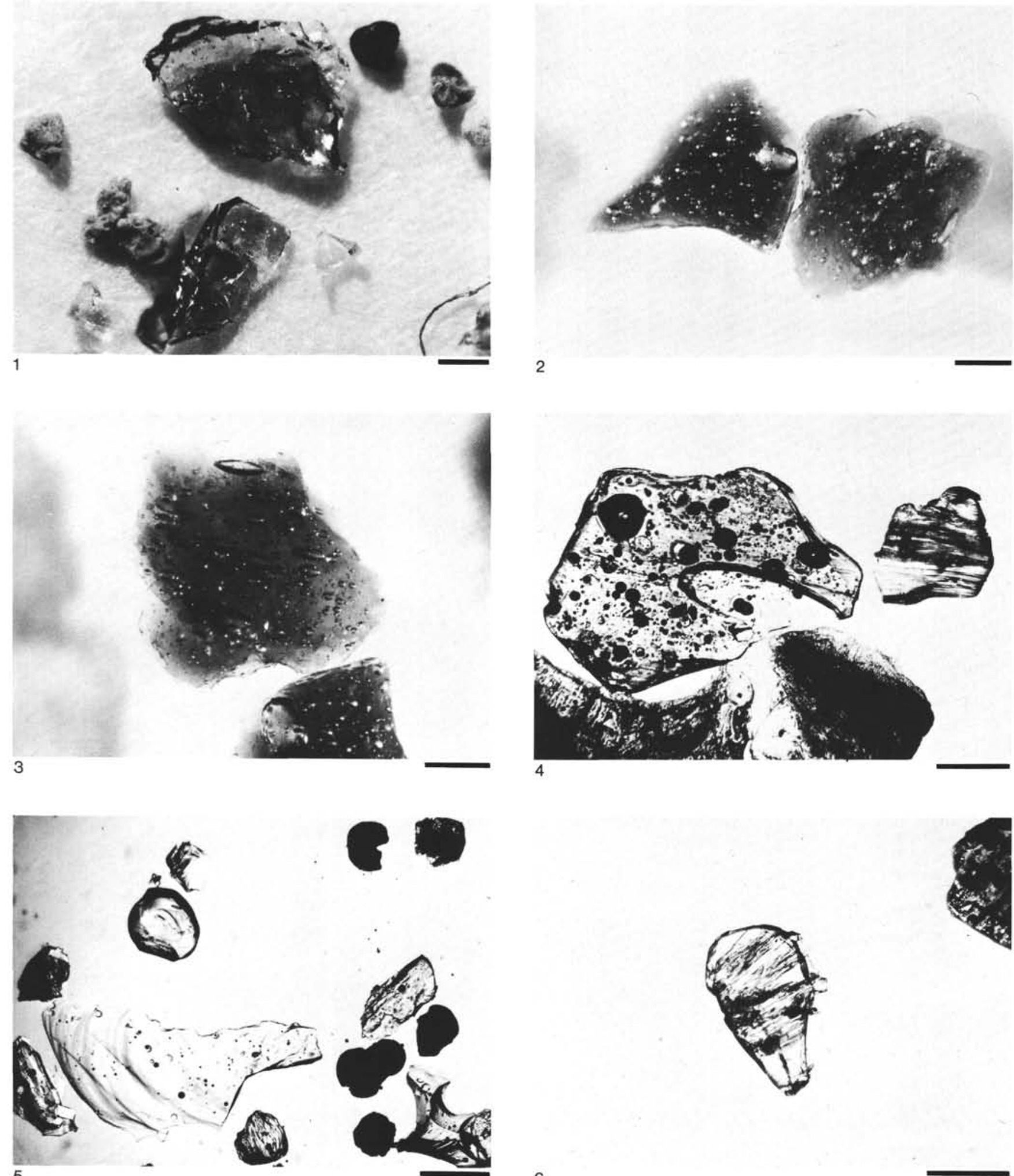

Plate 3. Glass fragments and microtektites (Sample 612-21-5, $118 \mathrm{~cm}$, late Eocene). (Scale bar $=0.5 \mathrm{~mm}$.) 1. Clear green glass shards with minor gas bubbles. Small colorless, irregular glass fragments. Dull gray glauconite grains and black pyrite aggregate. 2. Highly degassed, green glass fragments. 3. Green glass with fusiform gas inclusions. 4. Large fragment of green glass with numerous gas bubbles and fluid texture. Right: Irregular colorless microtektite with finely laminated texture (transmitted light). 5. Bubble-filled green glass shards, spherical to irregular colorless microtektites. Black pyritic chamber fillings of radiolarians (transmitted light). 6. Tear-shaped colorless microtektite with laminated surface, resulting from internal fluid texture (transmitted light). 

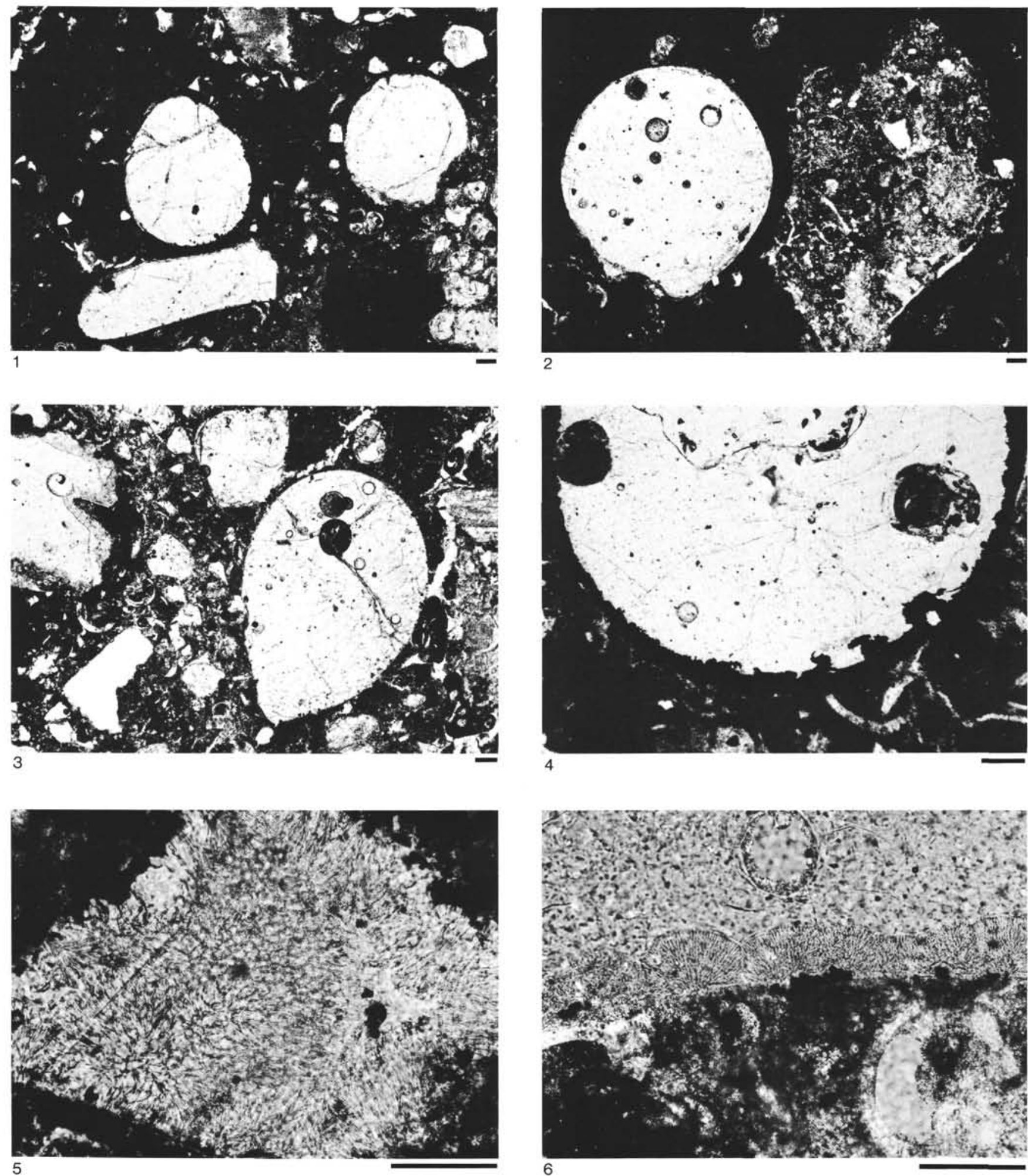

Plate 4. Photomicrographs of microtektites and glass shards (Sample 612-21-5, 111-114 cm, late Eocene) $($ scale bar $=0.1 \mathrm{~mm}$.) 1. Typical forms of microtektites: sphere with large pit, tear, and broken dumbbell. Irregular small glass fragments and silicate grains. Dull grain in middle upper part of photomicrograph is recrystallized glass (see fig. 5 for detail). 2. Bubble-rich microtektite sphere with large, rimmed pit. Irregular lump of silty mud (partly molten?). 3. Degassed tear-shaped microtektite, badly sorted irregular glass grains and shards; foraminiferal tests. Larger fragment in upper left part of photomicrograph displays light gray rim of alteration, often observed in the thin section. 4. Detail of microtektite sphere, surrounded by a sulfide border. Sulfide also penetrates along fractures deeper into the glass sphere. (Central part of sphere was broken out during preparation of thin section.) 5. Angular glass grain with alteration (recrystallization?) features. Rims bordered by sulfide. 6. Altered external zone of glass fragment. Lower part of photomicrograph is sediment with foraminifer test. 

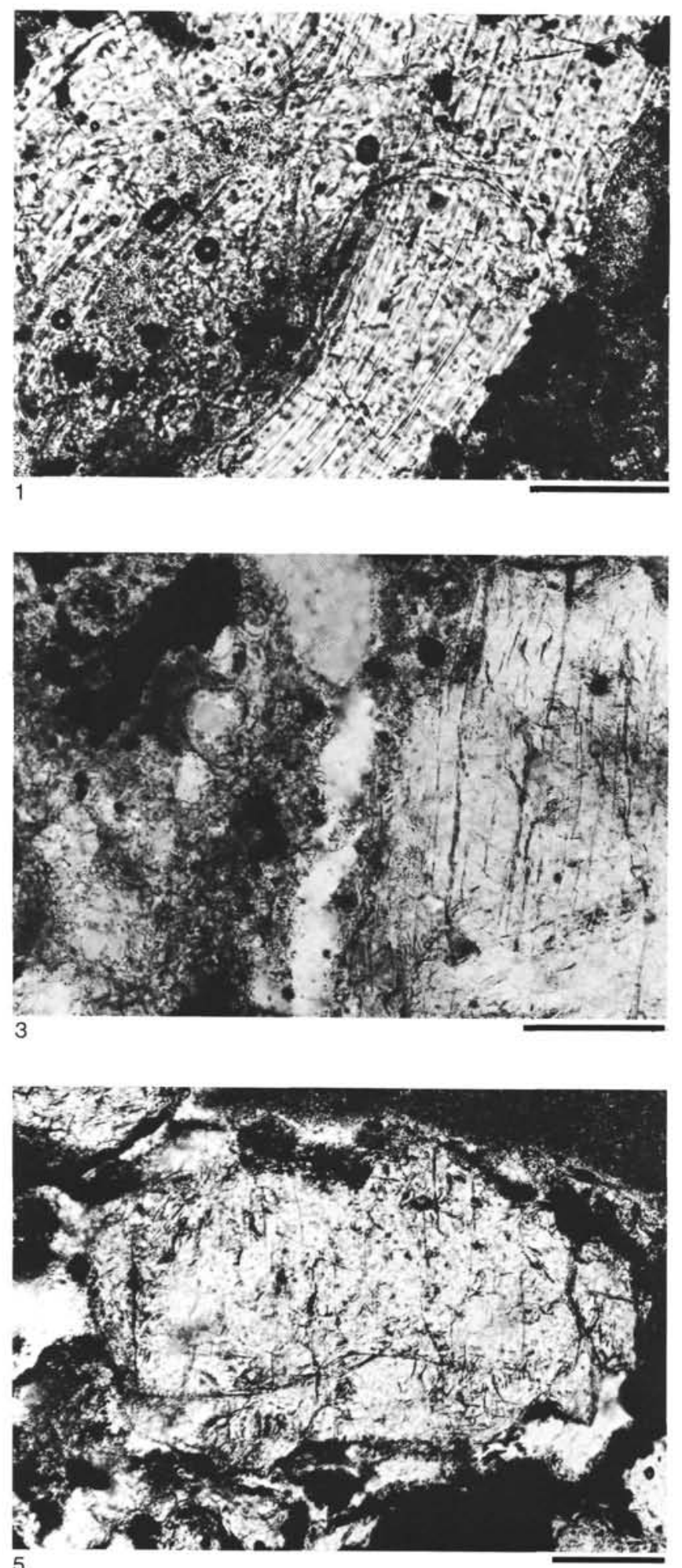
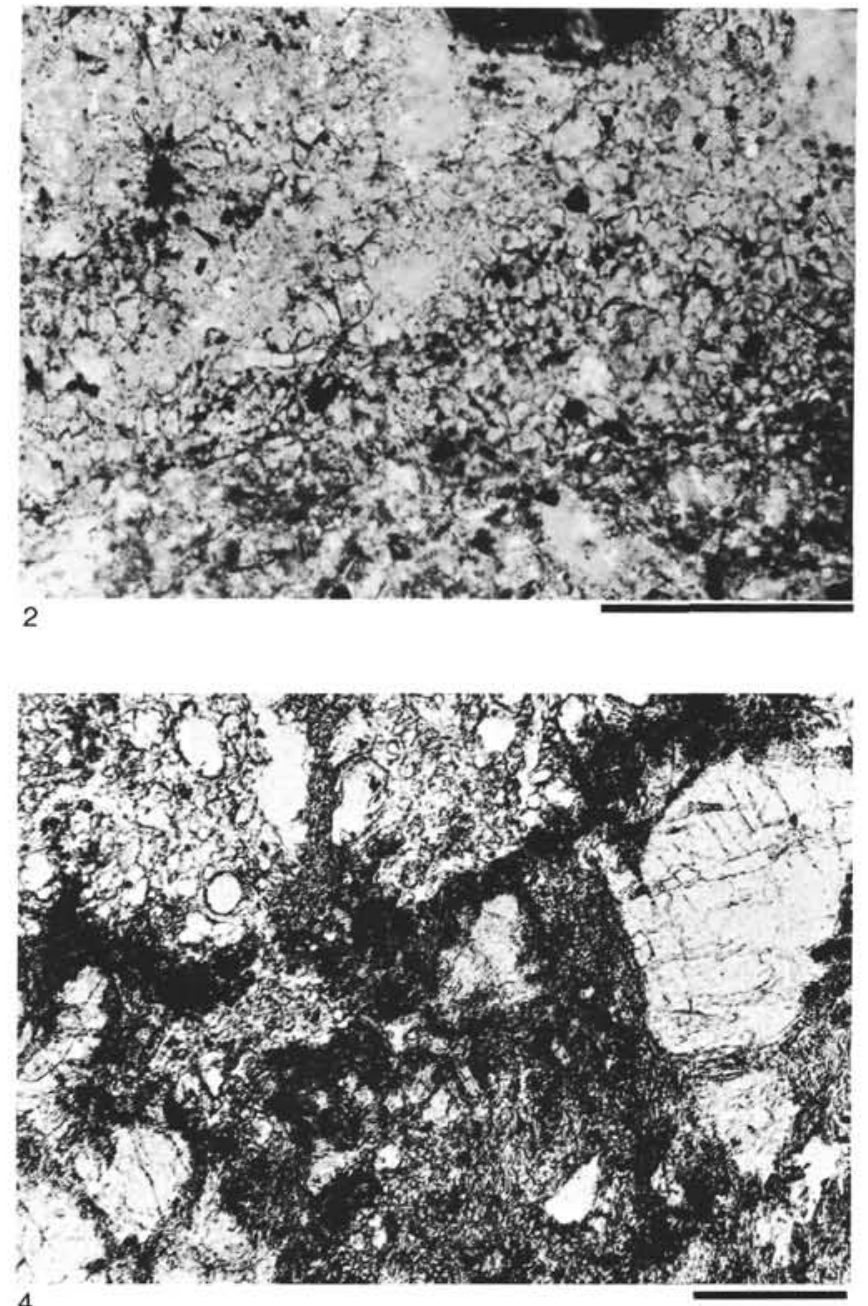

4

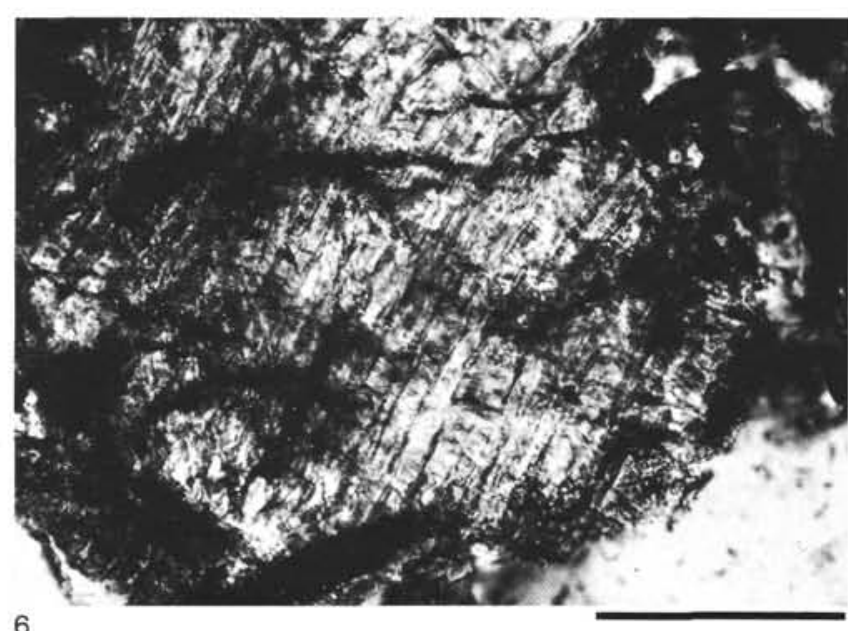

Plate 5. Photomicrographs of glass and mineral grains (Sample 612-21-5, 111-114 cm, late Eocene). (Scale bar $=0.1 \mathrm{~mm}$.) 1 . Irregular microtektite grain with fluid texture. Note perlitic fractures, gas bubbles, and central part rich in inclusions. Rim partly sulfide covered. 2. Detail of highly degassed, pumice-like glass grain. 3. External zone of same grain, displaying a row of larger bubbles and many sulfide inclusions. To the right of the grain is a highly undulatory, fractured feldspar (Nicols partly crossed). 4. Similar pumice-like glass and fractured quartz in Cocconino sandstone of Canyon Diablo meteorite crater. 5. Quartz grain of Site 612 sample with rhombohedral planar fractures (for further explanation see text). 6. Small feldspar grain with highly deformed cleavage plains and irregular zones of thetomorphic glass. 